\title{
A Fairy-Tale Noir: Rewriting Fairy Tales into Feminist Narratives of Exposure
}

\section{Danila Cannamela}

Penso che ci sono tanti mondi uno dentro l'altro. Ogni mondo non sa che esistono gli altri. I mondi stanno uno dentro l'altro ma non si toccano e nessuno può sapere cosa succede in tutti i mondi, ma sa solo quello che succede nel mondo che abita. È come nelle favole: Barbablù non può uscire dalla sua favola e sposare Babayaga e vivere felice con lei che sono anime gemelle. Sono mondi diversi, ma tutti nello stesso libro delle favole sanguinarie.

(Nicoletta Vallorani, Cordelia 67)

The arche-lithic is the twisted space of causality itself since the realm of faerie is the realm of fate [...]. We aren't there yet, but it does appear at this level as if some arche-lithic pixie dust is fogging our dualistic, anthropocentric spectacles.

(Timothy Morton, Dark Ecology 135)

Abstract: This article introduces the fairy-tale noir, a subgenre of fantasy-noir fiction that is particularly present in the work of Italian women writers, including Laura Pugno, Simona Vinci, Nicoletta Vallorani, and Alda Teodorani. This subgenre adopts fairy-tale topoi and characters to elaborate on the theme of vulnerability from feminist and environmental perspectives. Vulnerability is an intrinsic feature of fairy tales (texts that are continually performed and modified, but that remain "non-appropriable"); it is also a pivotal characteristic of the young protagonists of these fictional universes, who are often exposed to abuse. The twenty-first-century fairy-tale noir redeploys the discourse of bodily exposure typical of traditional fairy tales by engaging in an environmentalist reflection 
on the experience of exposure that human and nonhuman bodies share. The genre also adopts the theme of vulnerability as openness to change and uses the unconventional families of fairy tales to discuss recent social changes in Italian families. Finally, fantasy noir recasts vulnerability to violence as a potential space of empathy, or biophilia, with the broader, nonhuman "family." Exploring this overlooked genre ultimately shows how Italian women writers, who are still at the margins of the Nuovo Giallo Italiano, have successfully reinvented a male-dominated genre into a literary lens probing socioenvironmental concerns, first and foremost gender discriminations.

\section{Introduction: Beyond the Nuovo Giallo Italiano}

In "The Philosophy of Crime Novels," Gilles Deleuze contends that, unlike detective novels, which feature a teleological progression focused on the search for (and faith in) the truth, crime novels mire readers in an intricate reality that, based on the model of Oedipus' quest, is punctuated with failure, tragic irony, and trips down the wrong paths (82). Through this rough Oedipal journey, noir fiction unfolds a complicated capitalist system that "more willingly pardons rape, murder, or kidnapping than a bounced check" (84).

Situating crime and justice in entangled realities, the "Nuovo Giallo Italiano" (NGI) has successfully evolved, since the 1990s, into a nuanced genre that deviates from the "whodunit" British tradition by intermixing hard-boiled fiction, psychological thriller, noir, and even comedic elements. ${ }^{1}$ In their introduction to the 2016 special issue of Quaderni d'italianistica dedicated to crime fiction, Brigid Maher and Barbara Pezzotti stressed how, thanks to its inexhaustible hybridity, this multifaceted genre continues to "create meaningful literature able to deal with pressing issues in Italian society, in some cases acting as a pedagogical tool or contributing to national debates on identity, racism, or gender and sexuality" (11). Italian crime fiction did indeed find its captivating allure in "its ability to speak

\footnotetext{
${ }^{1}$ For a detailed analysis of the noir genre, see Amici; Giovannini; Jansen, Lanslots, and Vermandere. Their contributions illustrate how detective and noir fiction are two different yet very close genres that the Italian giallo has often blended. Here, I am generally referring to this giallo/noir blending. However, I will be focusing on fictional works that are more in line with the noir genre as they spotlight chaotic societies and evil power mechanisms rather than following the detection process.
} 
to and even influence the attitudes [...] of its wide readership" (Past 6), while problematizing readers' trust in a "conventional" truth that had been fabricated by the media and other powerful institutions (Amici 150).

However, while many scholars, including Nicoletta Di Ciolla, Elisabetta Mondello, Giuliana Pieri, and Luca Somigli, have examined Italian crime novels over the last few decades, demonstrating their role as powerful vehicles of social denunciation and impegno, other critics have voiced concern that the NGI might have paradoxically been defeated by its own success. As noir writer Loriano Macchiavelli recently remarked, crime fiction evolved from being a "virus nel corpo sano della letteratura" to representing a harmless media product that readers voraciously consume, immune to its disturbing action. ${ }^{2}$ Since the early 2000 s, the NGI's quasi-standardization into the so-called "Mediterranean noir" - a fine blend of laid-back lifestyle, pervasive corruption, and ironic fatalism-and the many marketing attempts to serialize its popularity have raised doubts regarding the genre's social engagement and creative experimentation. ${ }^{3}$ Unapologetic denial of moral order, disquieting representations of urban areas, and an over-indulgence in violence: are these scripted narratives still offering a scathing critique of Italian society? Perhaps they never did, critic Filippo La Porta contends in a 2006 article, in which he dismisses both detective and noir fiction as poor imitations of AngloAmerican models that keep Italian authors trapped in a stifling cage $(57,66)$.

Wu Ming I, in "Premessa alla versione 2.0 di New Italian Epic" (2008), takes a similar stance. Although the writer praises the compelling nature of earlytwenty-first-century crime novels, he compares later works to "cani mezzi morti accasciati in autostrada" (12). His bitter criticism echoes that of Tommaso De Lorenzis, who in 2005 announced the "Thermidor" of Italian crime fiction on the website Carmilla (https://www.carmillaonline.com/). He argued that the epoch of the noir "revolution" was officially over because, after masterpieces like Andrea Cammilleri's La presa di Macallè (2003), Massimo Carlotto's Arrivederci amore, ciao (2001), or Giancarlo De Cataldo's Romanzo criminale (2002), Italian authors stopped innovating the genre. Novels and countless television adaptations devolved into a "bazar criminoso," surrendering to a conformism that does not desecrate but, instead, empowers the institutions ("Termidoro").

\footnotetext{
${ }^{2}$ See Macchiavelli's interview with Agostinelli as well as his recent article, "L'Italia ha ucciso il romanzo noir."

${ }^{3}$ See Jansen, Lanslots, and Vermandere, in particular 10-12.
} 
While this lively debate opens further room for discussion, it is of note that the NGI detractors seem to be basing their critiques on a partial account of Italian crime fiction that virtually overlooks the work of women writers. ${ }^{4}$ One exception to this is La Porta, who, in his aforementioned essay, interestingly affirms that Simona Vinci is the only Italian author anthologized in the collection The Dark Side (2006) — a volume of Italian and American noir short stories—who truly succeeds in narrating "ossessioni e incubi reali" (61). Here, the "real obsessions" that Vinci describes in "La gabbia" are childhood memories of abuse that still haunt the victim-protagonist in his adult nightmares. La Porta's comment leads us to examine a rather unexplored question: What could be revealed about the innovating potential of Italian crime fiction if the genre were examined through the writings of women writers who, from the margins of the NGI, engage with the noir genre in a unique way so as to desecrate anthropocentric mindsets?

An exhaustive overview of Italian women's crime fiction is beyond the scope of this article; my goal, rather, is to trace the profile of a fairy-tale noir subgenre as it emerges in the works of Laura Pugno, Nicoletta Vallorani, Simona Vinci, and Alda Teodorani. ${ }^{5}$ Their dark "fables," populated with abused children and dysfunctional parents; magical animals and monstrous creatures; and trauma that often generates endless chains of violence, redeploy classic fairy-tale imagery into a chaotic evil universe that marries dark fantasy and realistic representations of crime by embracing either the perspective of the victim or "Cain's point of view." I argue that this reuse of traditional fairy tales reveals a fundamental "allegoritmo," a hidden narrative path that, according to Wu Ming I's definition, leads readers to access deeper meanings (27). For centuries, folktales have played an essential role in enculturating the child audience. In addition, these texts typify a sort of precursory platform of user-generated content, as their stories have been exposed to countless oral performances, regional variations, and transgenerational sharing. Pivoting on the formative function that such exposed (yet not-fully appropriable) texts exert, noir women authors have recast fairy tales into noir narratives that dislodge anthropocentric views of appropriation in their adult readers, while shedding new light on the threads connecting domestic, social, and environmental vulnerability.

\footnotetext{
${ }^{4}$ On Italian women's crime fiction, see Di Ciolla and Pieri.

5 The name "fairy-tale noir" was inspired by Raffaele Donnarumma's review of Sirene (Allegoriaonline.it), in which the Italian scholar defines Pugno's novel "una favola nera."
} 
Through their fabled noir, Italian women writers suggest that the vulnerability traditionally associated with feminine or feminized bodies should instead foster a broader cross-gender discourse. In their works, bodily exposure is re-conceived as a "politicized sense of permeability" (Alaimo 94), connecting human bodies with their socio-natural environment. Yet environmental permeability is also a textual feature of twenty-first-century noir fairy tales. Being permeable to social change, these fictional narratives adopt the folktale trope of the atypical family to give visibility to parental figures - same-sex parents, foster caretakers, female paternal figures - who testify to the evolution of Italian families beyond heteronormative models. Finally, their discourse on family involves redefining these human bonds as an interspecies kinship, rooted in the "fundamental continuity between humans and other animals" (Herman 3). In the fairy-tale noir, animals are more than symbolic helpers or tricksters, and yet they are not sublimated into anthropomorphic companions. They maintain their alterity, including a natural disposition to violence. Violence, though, is surprisingly transformed into a reservoir of interspecies empathy.

Here, after discussing how fairy-tale noir recasts folktales into a narrative of human-nonhuman exposure, I examine the genre's representation of a wide range of surprisingly similar families. The last section explores how embodied sufferance can foster a rediscovered sense of emotional "familiarity" with nonhuman life. Ultimately, by combining literary analysis, environmental feminism, and animal studies, this article pinpoints a subgenre of Italian crime fiction and examines the fantasy-noir lineage as an engaged creative space in which imaginative literature "deals with the basic relation between culture and nature in particularly multifaceted, self-reflexive, and transformative ways" (Zapf 4).

\section{From Female Vulnerability to Politicized Exposure}

Folktales and fairy tales, even those formally collected in print volumes-we may think of Giambattista Basile's Pentamerone (1634-1636), Charles Perrault's Tales of Mother Goose (1697), the brothers Grimm's Children's and Household Tales (1812), and Italo Calvino's Fiabe italiane (1956)—are texts characterized by intrinsic vulnerability. These stories of encounters and quests for people and objects have been exposed to centuries of oral performance, representing a set of narratives that is intimate, yet non-authorial and communal. Although, in a few cases, this collective reservoir has been appropriated, commercialized, and often 
refashioned to serve dominant-class ideology (Disney's movies are perhaps the most remarkable example), inappropriability is still a fundamental trait of the oral and folkloric roots of fairy tales.

Fairy tales may fall into a category that Giorgio Agamben has dubbed "inappropriable use," namely a type of use pertaining to the "very nature of [familiar] things" that we do not precisely own $(80,82)$. According to the Italian philosopher, "things" such as our language, our body, and our landscape share a precarious modality of belonging, constantly oscillating between appropriation and expropriation, a type of use that challenges the taken-for-granted notion of capitalist ownership. ${ }^{6}$ However, we should add that the common denominator of inappropriability resides in the fact that "objects" suspended between appropriation and expropriation are also more exposed, vulnerable, and affected. It takes only one act of appropriation for bodies to be abused, landscapes exploited, and language twisted, while the boundary between use and abuse often remains blurry. Conversely, the potential for change that exposure enables can produce new spaces of (self-)care and mutual respect, in which mutability becomes an emancipatory drive of sociopolitical transformation. Love itself, as French theorist Jean-Luc Nancy states, generates (and is generated by) an endless process of exposure- "the heart lives [...] under the regime of exposition." Thus, while "the dialectic is the process of that which must appropriate its own becoming in order to be, exposition, on the other hand, is the condition of that whose essence or destination consists in being presented: given over, offered to the outside, to others, and even to the self" (89). Embracing exposure as openness to a wide range of transformative uses, the fairy-tale noir recasts the performativity of folktales and their master narrative of vulnerable co-agency into a politicized discourse in which social and environmental issues commingle.

Before I explore more in-depth how Italian women authors have reworked the literary norms and social message of the noir genre, I will briefly suggest a parallel with feminist rewrites of fairy tales in British and American literature. Anne Sexton's poetry collection Transformations (1971) provocatively reinvents 17 of the Grimms' stories. In this revised context, Snow White is a "dumb bunny" (8), Rapunzel is involved in a lesbian relationship with an "old aunt" (35), Sleeping Beauty is an insomniac who "sho[ots] up with Novocain" (111), and "living happily ever after [is] / a kind of coffin" (15). The unifying morale of such ironic versions can be found in the lines of "Cinderella": the story "you always read

\footnotetext{
${ }^{6}$ See chapter 8, "The Inappropriable" (80-94).
} 
about" (53) is ultimately the one that transforms the struggles of everyday life into fake "darling smiles" or out-and-out taboos (57). If Sexton refashions fairy-tale characters through the filter of dark irony, Angela Carter, in the short stories of The Bloody Chamber (1979), turns traditional disempowered dolls into self-driven protagonists, so that folktales become gothic stories of emerging female agency, sexual desire, and unspeakable truths. Also featured in the noir works of Italian women writers, the reuse of fairy tales is a vehicle for a strong, albeit not always explicit, feminist commitment. These authors similarly strive to unveil the mechanisms of a "game" in which, in Carter's words, "every move [is] governed by a [patriarchal] destiny so oppressive and omnipotent" (34) that its pervasive appropriation of women, minority groups, and nature is revealed to be the exploitative system underlying enlightened western cultures.

As we have seen, fairy tales are inappropriable texts whose use remains suspended between written form and oral mutability, and between intimate childhood memories and collective imagery. Featuring a perturbing form of inappropriability, Nicoletta Vallorani's 2008 collection of noir short stories is titled Si muore bambini. The impersonal construction of the title might refer to the depersonalizing common destiny of abuse shared by her stories' young protagonists, who resemble dark alter egos of Snow White, Cinderella, and Hansel and Gretel. Yet the utterance "si muore bambini" comprises in its impersonal meaning an estranging "one dies a child" and an inclusive "we all die children"; it condenses readers' horrified detachment from the domestic violence that Vallorani narrates and their participation as accomplices in a system that - paraphrasing Deleuzemore willingly pardons child abuse, socio-economic inequality, and environmental violence than a bounced cheque.

In this fairy-tale universe deprived of its customary happy ending, readers do not access the typical Italian underworld ruled by mob bosses; instead, they are mired in a fantasy land that overturns the enlightened image of a liberal western society, transforming it into a fabled—yet disturbingly realistic-world of everyday disenfranchisement. Simona Vinci's novel Brother and Sister (2003) is indeed fascinating for its unresolved tension between gothic fantasy and dark reality. The book retells the last night together of three siblings (Cat, Mat, and Billo) who will be sent to an orphanage in the aftermath of their mother's suicide. The orphans' story of poverty and isolation is set in a remote "enchanted" forest of the Apennines that "parla, respira, si agita, geme, smette e si zittisce, poi riprende" (56). At a narrative level, the sleepless night of the three children intertwines with 
Cat's storytelling of "Little Brother and Little Sister," a Grimm fairy tale. The space-times of reality and fiction intermix as the mise en abyme features two siblings who are forced to leave their home: "Il fratellino prese la sua sorellina per mano e disse, da quando la mamma è morta non abbiamo più avuto un'ora di bene, la matrigna ci picchia ogni giorno e se ci avviciniamo a lei, ci manda via a calci” (35).

In a thrilling crescendo, the audience sympathizes with the orphans but later comes to wonder whether Cat was the murderer or the benevolent euthanasiaprovider behind her depressed mother's suicide. For readers, it is also difficult to determine whether the stepmother of the Brothers Grimm fairy tale, who does not formally appear in the siblings' "real" story, is their suicidal parent or a ghosting society that, while providing Cat and her brothers with charity donations, has confined this troubled family in a fabled "once upon a time" undermined by mental illness.

In Vinci's subtle discourse of entangled vulnerabilities and responsibilities, the forest represents an allegorical space in which a number of conflicting narratives converge. As Jack Zipes has noted discussing the Grimms' tales, the forest "allows for enchantment and disenchantment, for it is the place where society's conventions no longer hold true"; it is "the source of natural right," an alluring locus of social warning and transformation at the threshold of safety and peril (67-68). In the woods, Vinci's siblings face a threatening wilderness, surrounded by nocturnal birds, brambles, a pack of wild dogs, and sinister shadows. The children's katabasis into the wild symbolizes a transformative journey through a dangerous uterine nature- their mother's dark irrationality—-that, according to social standards, they must tame to access adulthood. ' Yet, to summarize "Paint it Black," a noir short story by Teodorani, nightmares and dark personifications are terrifying because they are fuelled by reality. As she writes, "i ragni — gli infiniti ragni - dei tuoi incubi" are not psychoanalytic projections but the material fallout of economic inequality: "e Freud non c'entra, c'entra la povertà" (La collezionista 31). Poverty as a "state of nature" - neither an exception nor a magic spell, but a necessary condition for capitalist appropriation to flourish-is ultimately the terrifying shadow that Vinci's fairy tale projects on its readers.

Like many other noir fairy tales, Brother and Sister does not disentangle its problematic narrative, leaving characters and readers to face their vulnerability in seeing their own "countless spiders" exposed. Throughout the narration, the

\footnotetext{
${ }^{7}$ On the symbolism of the forest, see in particular Bettelheim and Zipes.
} 
audience comes to share with Cat the desire to hide a shameful guilt for her family struggle. The girl wishes that her bones could explode in "mille pezzetti, come fossero fatte di ghiaccio, tante schegge che andranno a conficcarsi dappertutto e poi si scioglieranno senza lasciare alcuna traccia" (48). Yet, if we transpose Cat's desire to disappear to a broader geological scale, Vinci's fairy-tale noir poses a further threatening question: in the epoch of the Anthropocene, in which humans have physically marked their transforming agency on Earth, can we hide the vulnerable, and often shamefully dark, process through which we constantly affect and are, in turn, affected by the material world?

Going back to the initial considerations regarding the exposed textuality of fairy tales and their ambiguous relational perspective in which an enclosing "we" and an impersonal "one" overlap, we can more clearly pinpoint the feminist "allegoritmo" of the fairy-tale noir. Folktales and fairy tales are characterized by interactions that, as Vladimir Propp has extensively analyzed in Morphology of the Folktale (1928), are fundamental in triggering a series of other actions and counter-actions, shaping a multi-agentic network of relations. Suitable examples are the chains of events triggered by Snow White's bite into the poisoned apple, Little Red Riding Hood's walk across the forest, or Cinderella's shoeless escape. From a posthuman perspective, fairy tales are particularly compelling, as they embrace a relational ontology in which "we" and "one" merge in a transforming environment. Androcentric cultures use these texts to highlight the psychophysical vulnerability of female or feminized bodies; by contrast, fairy tales could be interpreted as narratives that show the mutual affect between humans and nonhumans. Within this fictional discourse of shared exposure, feminist voices acquire a renewed political value; as Stacy Alaimo contends, they "can be kept in play by imagining the plinth as a pivot between the vulnerability associated with the feminine and the resolute occupation of a politicized sense of permeability that insists on intersubjective, intercorporeal, and inhuman intimacies," counterbalanced with "the conventional armor of [masculine] impermeability that blithe capitalist consumerism requires" (94).

A politicized sense of body-world or "we-one" permeability emerges in Vallorani's Visto dal cielo (2004), a noir novel set in Milan in the aftermath of the disquieting events of the Genoa G8. During this 2001 political summit, antiglobal protests escalated in street clashes between demonstrators and police. In particular, the police raid at the Armando Diaz school, which housed a group of Genoa Social Forum activists, and the later brutalization of detained protesters, 
are collective memories of trauma. Recalling the unsettling images of the Genoa G8, in which vulnerable male bodies muddled the divide between justice and crime, Visto dal cielo opens with a graphic description of the martyrized corpse of Nicholas Gutierrez (Guz). In Vallorani's fictional rewrite, this teenager of Hispanic origin was tortured and set on fire in a high school in Pasteur (a working-class neighbourhood in Milan) in the midst of a wave of student protests. The scene of the crime is set at a second-tier trade school, a highly multicultural place where the city "disposes" of the unpleasant residue of its global economy. Mobilization of labour, ethnic diversity, and unequal distribution of capital are "dumped" in a school that attracts and secludes primarily children of immigrants. And it is likely not a coincidence that the unusual detective featured in this novel is Zoe, a street cleaner who investigates Guz's death while managing actual waste. Intertwining environmental and social discourse in an intercultural textuality that purposefully "stains" the Italian language with the languages of immigrants, including Arabic, Chinese, and Spanish, Vallorani pushes her audience to read into the garbage left behind by a worldwide flow of capital.

Zoe conducts her investigation together with a rescue dog, Zorro, and a group of Guz's disenfranchised friends. She is also assisted by her late mother who, though having been cremated and stored in an empty Nutella jar (a further wink to the global economy), cyclically appears as a ghost to tease her daughter. This fairy-tale noir, in its alternation of serious and ironic tones, embraces a living continuum in which even garbage and phantoms are affected by a fastchanging ecosystem. Their residual humanity participates in a complicated plot that, though never revealing the identity of Guz's killer, reveals another disturbing truth: more than 20 years after the cloning of Dolly the sheep, we have all invisibly become bio-tech mutants, "figli di viale Monza, pecore con due teste e un numero variabile di zampe" (8). This global village of mutants exposes its vulnerable side in two ways: through a newly emerging "carbon-heavy masculinity" (Alaimo 91) that reaffirms nationalisms while worsening the environment, and through the slow sociocultural transformation that counterbalances the globalized speed of hightech obsolescence. Touching on this cultural gap, Vallorani depicts a backward twenty-first-century Milan in which one of Guz's classmates is nicknamed with the racial slur "Ciainamen" (the Italianized version of "Chinaman") for being an Asian immigrant (69); Tutù, a girl in Zoe's group, wishes she had been born male to escape sexual harassment (74); and Nutis, Zoe's paraplegic colleague, fights every day to assert his "normality" (20). By contrast, however, true abnormalities, 
like having a father as violent as a serial killer, remain a form of concealed domestic "waste" (249).

In Vallorani's writings, as well as in the noir works of Pugno, Teodorani, and Vinci, character names are fundamental devices in othering the main personas from their social setting and make them stand out. This strategy includes the use of exotic first names, which are often monosyllabic (Guz, Cat, Cal); literary references, such as the Shakespearean names Ariel and Cordelia; and nicknames. A particularly interesting case, in this list of eccentric naming choices, is Zoe. Detective Zoe is killed during the investigation, turning into a ghost herself, yet her name is the clue suggesting a possible escape from a global system of abuses. Etymologically, the name "Zoe" evokes a life force that Rosi Braidotti has defined as a "productive and immanent force" pervading a relational territory of cross-species and non-anthropocentric alliances (32). Braidotti's view combines Deleuzian vitalism with a feminist thought that posits the corporeal and geocentric dimension of zoe as a fundamental aspect of human bios, offering a "materialist, secular, grounded, and unsentimental response to the opportunistic transspecies commodification of life that is the logic of advanced capitalism" (32). In Vallorani's novel, Zoe- a creative force linking a number of human and nonhuman agents-is set in opposition to the global necropolitics that the impersonal figure of the serial killer embodies. This unnamed shadow is ultimately dangerous because his goal is "quello di trascinarti con sé nella sua propria morte" (347), into self-extinction. Adding a social nuance to her environmentalist message, Vallorani provocatively ties her discourse on zoe to the debate on immigration. It is indeed Zoe's best friend, the North-African lawyer and immigrant Mossàd, who offers a possible interpretative key for the novel: paraphrasing the New Testament, he wonders whether the disenfranchised are perhaps the salt of the earth, its (re-) vivifying immanent force (106).

In Pugno's and Teodorani's noir fairy-tale works, the feminist discourse about zoe is similarly central, but the environmentalist message becomes more visible. Emphasizing the representation of violated bodies, Pugno and Teodorani stress, in different ways, a vulnerable exposure that is at the base of the ecological view of organisms as interacting agents. In Sirene (2007), Pugno recounts an apocalyptic "fantabiological narrative" set during the outbreak of a highly contagious skin cancer caused by sun radiation. ${ }^{8}$ During the sanitary crisis, the Yakuza

${ }^{8}$ In "Flying Saucers," Saiber coins the term "fantabiological narratives" to designate the sciencefiction narratives "that investigate the manipulation of human life." 
(Japanese organized crime) has expanded its business to Underwater, a subaquatic territory where illegal farming and the prostitution of sirens have become a lucrative activity. Sirene focuses on Samuel, an employee of the farm, who dares to have intercourse with a siren and thereby generates Mia, a human-animal hybrid. Mia is later sexually abused by her reproductive mates and Samuel.

From a traditional ecofeminist perspective, the motif of violent penetration expresses a criticism of male dominance over women and over a feminized nature. However, Pugno's novel embraces a cross-gender discourse of vulnerability that includes not only female or feminized bodies, but also heterosexual masculinity. The sirens cyclically "penetrate" their male partners with their sharp teeth after copulation; Mia bites into Samuel's flesh while they are imprisoned together in a pool; and, at the end of the novel, she "vampires" her father's corpse to seek nourishment. In addition, the novel expands the discourse of shared humannonhuman exposure through the episode of the cross-dressing man-siren (40-44). Samuel recalls how he once saw a man wearing a siren costume and plastic breasts to celebrate Iemanjà, a native goddess of the sea. The man confesses to Samuel that he wants to die, and Samuel wonders whether offering the body of that "siren" to the orixas - demi-god ancestors who are believed to represent forces of nature-could liberate humans from evil (both the orixàs and Iemanjà are divinities venerated in Yoruba religions). He then throws the man into the sea along with his prosthetic breasts, dipped in honey, as a sacred offering. This cross-dressed body, where femininity and masculinity merge, is immersed in water and devoured by the ocean, standing as a dark allegory of our intra-connection with nature beyond gender divisions, a connection rooted in the intrinsically inappropriable nature of our bodies.

Pugno further investigates the theme of cultural and environmental permeability in La caccia (2012), a fairy-tale noir that recounts in parallel the death of a mysterious woman —an elf-like personification of nature — and the story of two telepathic brothers, Nord and Mattias. In a complex game of cross-references, all the actions in the novel are connected: Nord hunts for a mythical reddish beast, which is perhaps the beautiful red-haired woman; yet, in the act of striking his prey, he wounds his own body, and Mattias physically and mentally experiences his brother's pain. The combined images of Nord, the hunter, and his self-inflicted pain spreading outside his body elicit a geopolitical parallel: they evoke the appropriation of resources that nations in the North of the world have undertaken for centuries; still, these images also address the global side effects of colonial 
politics and culture-from economic unbalance to environmental crises. Both at a linguistic and thematic level, the novel reuses the motif of water to stress how nature and culture permeate each other. Through this "sostanza viscida e viva" (60) contained in oozing human bodily fluids like sweat and blood, Pugno highlights a virtually invisible system of communicating vessels through which zoe trespasses human and nonhuman matter. Oozing fluids become material metaphors of a trans-corporeal co-suffering, as in this passage describing the scene in which Nord is wounded:

Riesco a mantenere quel poco di lucidità che mi serve a raggomitolarmi, a offrire la minor superficie vulnerabile agli spunzoni di roccia che mi tagliano la carne, alle erbe che la graffiano, ma è tardi. Una lama di roccia mi ha già squarciato la gamba destra e sento il dolore lacerante, il sangue che cola inzuppando il tessuto della tuta termica, sento il suo calore diffondersi da dentro a fuori dal mio corpo [...]. (83)

The painful intimacy connecting human bodies and the environment is expressed in a more-violent fashion in Animali da macello (2016), a short novel written by Teodorani in collaboration with Simonetta Hofelzer. The book was released in 2016 in the format of a "libro millelire," an editorial series of Stampa Alternativa, the books of which were originally sold for one thousand lire and sold today for one euro. Animali da macello tells the story of Karl, a young environmentalist who would turn into a merciless "eco-punisher." His youth at a sustainable farm was perceived to be as odd as the lifestyle of Amish people, and, as he continues explaining, his nickname, Cal, sounded biblical (3). Cal's childhood is in fact a modern retelling of the Old-Testament story of Abel (his father) and Cain (his uncle); the latter eventually succeeds in destroying both the family and the farm to align to the standard of industrial production. In the aftermath of this trauma, young-adult Cal takes revenge by inflicting on people the same pain that they inflicted on animals: he scalps a furrier to make fur coats, produces foie gras from human liver, boils a manufacturer of silk to peel away his precious skin, vivisects a scientist to test products, and poaches hunters. Prompted by a comment about her portrayal of excessive violence, Teodorani has argued that the carnage described in her noir writing should be considered neither "gratuitous" nor spectacularized. ${ }^{9}$ She contends that, while sensational cruelty, such as animal

\footnotetext{
${ }^{9}$ For more on this, see the interview with Stradanove.
} 
cruelty, is often a rhetorical device used by writers to avoid facing a truly shocking reality, she quite literally engages in what we could define as Socratic "maieutic writing." Teodorani vivisects human bodies and, in a peculiarly maieutic way, allows animal and environmental sufferance to erupt from the human flesh in pain. Just as disgust may arise when we see our bodies physically "break" and witness organic matter oozing from them, so, too, is it disturbing when we witness the carnage of Animali da macello, as it shows how "the ultimate object of disgust is bare life itself, life deprived of [its] protective barrier" (Krečič and Žižek 66)—nature brutally exposed to death.

Through a variety of storylines and styles, the fairy-tale noir transforms the exposure that typically characterizes folktales and female bodies into a vulnerable openness. This genre turns shared vulnerability into a violent awakening call to a socio-environmental politics of care, an aim that lies outside the capitalist agenda of impenetrability and consumerist appropriation.

\section{Every Family Is Alike, in Its Own Way}

In Visto dal cielo, Vallorani's narrator seems to parody the opening of Leo Tolstoy's Anna Karenina - "Happy families are all alike; every unhappy family is unhappy in its own way"-affirming that families are indeed all alike because of their struggles: "Alternative o tradizionali, nucleari o allargate, finte o vere, documentate o inventate, sono strutture che producono dolore in quantità e abbastanza lacrime da alimentare una centrale idroelettrica" (381). Commenting on the representation of family in noir writing, Giuliana Pieri and Lucia Rinaldi have highlighted that Italian women crime writers tend to focus on family relationships much more than male narrators (116). Women authors, through their criticism of patriarchal constructs, propose a nonconformist portrayal of family as a "chaotic, nonhierarchical, but emotionally rich environment, often devoid of male presence" (Pieri and Rinaldi 125).

However, while undermining patriarchal norms is definitely an objective of the fairy-tale noir, this subgenre does not fall into a binary that sets patriarchal order and the chaos of non-traditional families in opposition. Rather, this subgenre aims to show that any family - be it unconventional, traditional, nuclear, or extended—shares an "inappropriable" economy of affects, a non-monetizable potential that makes this community a crucial yet also vulnerable environment 
of social transformation. ${ }^{10}$ In positing exposure to change as the fundamental trait unifying families, the fairy-tale noir combines the educational function of childhood literature with estranging humour. Ultimately, the pedagogical goal is to unveil the unfamiliarity of socially normalized bonds and the familiarity of seemingly unnatural relationships. The fairy-tale noir, through its redefinition of the interrelated notions of family and familiarity, acts as a literary sensor of both the changes and embodied "toxic" narratives that have affected Italian families in the last decades, spanning the struggle for civil unions and equal rights for LGBT couples; the high incidence of domestic femicides; and the debates spurred by "Family Day," an annual event advocating the preservation of the traditional family.

In twenty-first-century noir fairy tales, the teleological happy ending of fairy tales, in which marriage predictably affirms patriarchal values and gender binaries, is undermined by references to (intra-)narratives that counterbalance this finalism. The abusive Barbablù who kills his wives; the extended family of Snow White and the dwarves; evil step-mothers and nurturing nonhuman agents are all figures who, in different ways, muddle the image of the married heterosexual couple as the sole possible happy ending. Fairy tales thus become ambiguous archetypical texts that, while fostering a normative narrative, question the assumption that it is possible to normalize families by fitting them into a standardized formula.

Making the hidden complexity of fairy-tale families visible, noir women writers create stories in which readers, like Pollicini in fabula, are in charge of retracing the path to a happy family life. Yet, does this path exist? Vinci's Brother and Sister presents "normality" as a sort of spell cast on the three siblings who are destined to pay the price for not having a standard middle-class family. In an earlier novel, Dei bambini non si sa niente (1997), Vinci reflects on the fact that the dividing line between normality and abnormality is very thin, somewhat imperceptible: Martina, a girl raised by a "happy" middle-class couple, is suddenly involved in an innocent sexual game that eventually escalates to the sadistic abuse of 10-year-old Greta.

The issue with defining family standards becomes even more complicated in Teodorani and Hofelzer's novel. Cal, the protagonist of Animali da macello, comes from a family of farmers that is ultimately destroyed for being oddly in harmony

\footnotetext{
${ }^{10}$ On the critique of patriarchal families and the representation of a more-diverse pattern of family relationships in crime fiction, see Cicioni and Di Ciolla, Differences, Deceits and Desires (section 3); Di Ciolla's Uncertain Justice (chapters 2 and 3).
} 
with nature. As the protagonist explains, during his childhood, he had learned from his grandfather a basic lesson: "la natura non deve inchinarsi all'uomo e ai suoi bisogni e [...] l'unica maniera di sopravvivere noi, come razza umana, è di seguire i ritmi delle piante e degli animali, di essere noi ad adattarci ai loro cicli e ai cicli delle stagioni" (7). Nevertheless, when his grandfather dies, Cal's uncle refuses to maintain the sustainable yet less profitable production of the family farm. He succeeds in converting the organic farm into high-intensive cultivation, while Cal's father commits suicide. Paradoxically, it is not by transgressing natural laws, but by observing them, that this family is led to ruin.

In Vallorani's Visto dal cielo, family (ab)normality is the topic of both serious reflection and mockery. The novel portrays an eccentric extended family, in which Zoe is a truly unconventional single parent: the street cleaner not only becomes a strong parental figure for the teenagers who are investigating Guz's death, but she is also the foster parent of Agata, the daughter of her best friend. The 14-year-old girl has never met her biological father, and Zoe—a heterosexual woman-performs a paternal role for Agata, who calls her "papà." The novel, through its portrayal of unique family relationships, unsettles fixed parental roles. Gendered family constructs become ironic refrains that are continually re-enforced, exploited, and deconstructed, suggesting that heteronormativity has very little to do with the rich and diverse bio-force of zoe. As the following excerpts emphasize, Visto dal cielo highlights how gendered family models are conveniently crafted and manipulated:

(Zoe) - Adesso mi racconti quello che hai fatto.

(Agata) - Perché?

(Zoe) - Perché sono tuo padre: ecco perché.

(Agata) - Ah sì? E dov'è il pisello? (229)

(Zoe) - Pinocchio, ti si allunga il naso.

(Agata) - Meglio un naso lungo e una vita felice, papà.

(Zoe) - Non chiamarmi papà. Poi felice con chi?

(Agata) - Perché, felici da sole non si può?

(Zoe) - Non credo.

(Agata) - La devi smettere con questa fissazione della famiglia.

(Zoe) - Non sono fissata.

(Agata) - Non è tutto oro quello che luccica.

(Zoe) - Se tu avessi avuto una famiglia normale, forse non saresti così. 
(Agata) - Sì, e se il nonno aveva cinque palle era un flipper. (Zoe) - Non l'hai conosciuto, tuo nonno. E neanche il tuo padre vero, se è per questo. (292)

Presenting both sides of the equation - the affirmation of traditional family roles and its destruction-Vallorani does not ask readers to choose between two opposite models, but to explore the possibility for diverse types of families to coexist and experience similar everyday struggles. Family, in the definition of Nutis, should ultimately be a community that allows each member to feel inclusively free; as the character affirms, "non devi restare con la famiglia che ti trovi, se quella non riesce a renderti libero di vivere" (368). Nutis' perspective suits the liberatory journey that Cordelia, another young protagonist of Vallorani's fictional universe, undertakes. Cordelia is "una bambina con problemi," as her mother repeatedly tells her. The girl, who is likely suffering from a form of autism, engages in a fantasy quest to find her "colour" while escaping from the white Sherlock-a metaphor for her silence. The journey, which takes place in an afternoon of unsupervised wandering around Milan, brings Cordelia closer to a variety of people who, like her, cannot find their colours beyond pre-imposed race, gender, or class: a negro (as this girl without filters addresses a black street vendor), the homeless "signor d.," and a young woman "che sembra un ragazzo" silently share with Cordelia an intense non-biological familiarity.

The reflection about family complexity is equally central in Pugno's writing. In Sirene, when, at the end of the novel, Samuel sets Mia free and then dies, the siren uses her father's body as a reserve of food from which she sucks blood (142). In a sudden inversion of roles, the abusive father becomes a paternal nourishing mother. Mias vampire-nursing marks an interspecies rite of passage through which a female hybrid species will carry on life on earth. ${ }^{11}$ From a posthuman perspective, Roberta Tabanelli has read Pugno's novel as a response to a humanity that has used cultural and bodily binaries as the main weapon to violate female complexity (13). Tabanelli's interpretation can provide further insight into Pugno's more-recent novel, La ragazza selvaggia (2016), which tells the story of Dasha, a girl who has lived in the woods for years, behaving like a wild animal. Once rescued, Dasha appears as a sort of fantasy beast, a true outsider of human culture, who eventually abandons her family to return to the woods. While the girl is violent with her family members, she is simultaneously violated by them,

\footnotetext{
${ }^{11}$ For an in-depth analysis of Sirene, see Rushing and Tabanelli.
} 
as they deny her diversity, reducing it to uncivilized animality. In this case as well, a set of strict binaries - human/nonhuman, culture/nature-is adopted to flatten the richness of Dasha's womanhood. And yet this natural complexity is not solely female, or human, but broadly extends to animal and vegetal natures, strengthening our intrinsic familiarity with the nonhuman; as Vinci writes, "Ė nella natura del capriolo correre per i boschi e rischiare di essere ucciso dai cacciatori, non può farci niente. Vale anche per le persone, no?” (68).

By challenging standardized views of family and gender roles, fairy-tale noir texts perform an ecological function: they embrace an environmentalist perspective that does not appropriate (or distort) laws of nature to affirm sociopolitical agendas, but, rather, identifies nature with an allegory of the human embodied potential for cultural change - an inexhaustible reservoir of vital complexity. ${ }^{12}$

\section{Violence and Kinship}

In a 2015 monograph exploring animality in children's literature, Amy Ratelle argued that fairy tales are peculiar texts that, while helping configure the identity of younger readers, also counter the main pillar of western subjectivity, namely, the privileged difference of the human rational animal from other living creatures (4). In Visto dal cielo, Vallorani openly turns this divisive paradigm on its head, as her narrator affirms: "Da che mondo è mondo i cani sono sempre stati più svegli degli esseri umani. E mi meraviglio che le menti più brillanti della nostra generazione non l'abbiano capito. La sorte è una gran burlona, e noi siamo meno rilevanti di quanto pensiamo [...]" (157-158). In Animali da macello, a witty fox explains how humans' cruel negligence of ecological interconnectedness has impacted the lives of both animals and people: "Mi sto estinguendo, anche se pochi lo sanno. Non è una gran perdita, penserai tu. Avrai solo più ratti, più serpenti, più scarafaggi e meno insulse favolette che mi riguardano" (17).

Generally speaking, in fairy-tale noir works, the presence of speaking animals, animated nonhuman characters, and out-and-out hybrids like Pugno's Mia, who "non era più una bestia" (31) and yet was still "meno di un cane" (133), resonates with the non-anthropocentric counter-discourse Ratelle individuates in childhood literature. It may be asserted, though, that in positioning animals as peer subjects, this subgenre betrays a moralizing oversimplification of nonhuman

\footnotetext{
${ }^{12}$ Here I am drawing from Marchesini's reflections on the manipulation of more-than-human norms — be they religious or natural— to justify human social privileges and divides (291-292).
} 
nature into an essentialist locus amoenus. However, as we will see, giving a voice to animals reveals a more-complex discourse, which addresses the question of "natural violence" from an intriguing perspective of kinship.

In fairy-tale noir texts, redefining family complexity involves broadening the boundaries of family not only beyond patriarchal binaries, but beyond the human species itself. In "Choukra," a science-fiction noir short story published in the collection Si muore bambini, Vallorani problematizes the notion of interspecies families through a post-colonial allegory. The story is set in Choukra (which, "[i] n Arabo, più o meno, significa 'grazie'," 43), a planet populated by blue creatures and a few terrestrial scientists. Choukra natives, the "Uomini Blu," have some distinctive habits: they wear blue caps made of kilia, the skin of their dead, and engage in a type of free orgiastic sexuality. The terrestrial migrants slowly adapt to the lifestyle on Choukra and even conceive hybrid babies. However, for these migrants, integration involves rethinking their role as scientists: they ultimately refuse to run research on their alien companions, as understanding life on Choukra "era come cercare di infilare una vite in un foro troppo stretto: se avessimo insistito, saremmo riusciti a farlo, ma forse la cavità, allora, sarebbe diventata troppo larga per tener su quello che volevamo appendere" (45-46). When the planet is invaded by terrestrials, the colonizers exterminate the locals, including the human hybrids, to make kilia leather goods, and history repeats itself: "L'umanità fa rotolare un macigno su tutta una razza e poi si volta indietro a vedere cosa è rimasto di utile, di vendibile" (52). In Vallorani's short story, anthropomorphizing the otherness of the blue beings and dehumanizing colonial attitudes towards the nonhuman is a powerful strategy to cast doubt on notions such as "humanity" and "humane," which are too often considered to be interchangeable words.

Vallorani's literary provocation acquires scientific relevance if we analyze it through the lens of Animal Ethics scholar James Serpell. Retracing an "alternative" history of humanness that spans from pre-agricultural societies to the Victorian age, Serpell demonstrates that while primitive societies of hunter-gatherers were culturally rooted in a strong ethic of respect for animal prey, starting from the nineteenth century, western culture distortedly connected the fostering of sympathetic feelings for animals as a mark of civilization. This mindset was progressively revised to enforce and justify human dominance over the nonhuman; thus, for Serpell, far from being an enlightened achievement of (western) culture, humanness is a "'natural' human propensity that needs to be actively suppressed or denied in order to engage in acts of animal abuse or cruelty" (47). 
Serpell's view of civilization not as a detachment from a "potentially 'brutish' animality" (47) but as an actual possibility of respectful co-belonging can guide our investigation of Teodorani's ethical paradigm, which paradoxically arises from animal bloodshed. In Belve (2011), a novel that intermixes science fiction, fantasy, and eco-thriller, the violence of predators is connected to primal mores, which were later repudiated and deemed savage; the narrator even wonders if " $[\mathrm{u}]$ n uomo 'civile', un esemplare del tecnologico ventunesimo secolo, per esempio, sarebbe stato in grado di acchiappare la sua preda per poi ucciderla con le sue mani, con i suoi denti, guardandola negli occhi?” (65). Here, Teodorani is hinting at western culture's practice of concealing violence and guilt by removing, for example, any trace of butchery from the neat packaging of supermarket meat items. Yet is consuming the meat of farmed and abused animals not a hypocritical and ultimately cruel concealment of a violence that is bearable only because the death of the animal has been hidden? In Animali da macello, Teodorani and Hofelzer further elaborate on the concealed meaning of violence, recounting Cal's transformation into a sadistic eco-punisher. The protagonist's infancy is a fabled time of lay Franciscan life, in which Cal lives in harmony with his "altri fratelli" (3), the animals. His childhood combines the Romantic myth of innocence with the notion of biophilia, an emphatic kinship with the natural world that primates and infants share. According to scientific research, this innate empathy is tied to our capacity to develop emotions and could resemble "our natural ability for language or culture" (Verbeek and Waal 1).

Examining Cal's regression to predator status in light of Serpell's alternative history of humanness, we can see how the protagonist's transformation is triggered by a breaking of biophilia in the aftermath of his uncle's forceful implementation of an approach to farming based on domination rather than on mutual trust. Cal's peculiar fall from Eden first turns him into a castaway victim, and then into a punisher whose behaviour recalls the serial killer in the movie Seven (1995), who is inspired by the system of punishments in Dante's Inferno. However, the eco-punisher's revenge also enables a process of sympatheia, a carnal and spiritual sensation of "feeling with" founded on a shared human-nonhuman vulnerability. Once again, we see how the massacres narrated in Animali da macello foster empathy in the readers through a violent animalization of the human and humanization of the animal.

This strategy resembles the style of Ivano Ferrari's Macello (2004), a collection of poetry in which this Italian poet elaborates on his experience working in a 
slaughterhouse. As Matteo Gilebbi highlights in his analysis of Ferrari's collection, "becoming animal inside the slaughterhouse means [...] encountering the animal in the space of its (and our) suffering, in order to be able to stop the mechanism of inhumanity, of speciesism, of slaughter" (53). In Ferrari's poetry, the slaughterhouse is an arena of violence where pity evolves into an empathic interspecies relationship. In a similar way, in Animali da macello the corporeal intensity of violence annihilates cruelty, generating a redeeming sense of pietas - in the ancient meaning of an embodied blending of religious sentiment and moral duty that reconnects humans to their fellow living beings. Recast in an environmental context, pietas becomes the virtue that allows us to acknowledge a lost biophilia and realize that insofar as we perceive the environment and are in turn perceived by it, we are also exposed to its "gaze" and "touch."

Pugno has further elaborated on the theme of violent exposure, clarifying that, for humans, animal violence stands as a connecting element, "a dark and opaque residue, an oil that, through physic-chemical transformations, has lost its original properties" (private interview). However, we may add, only humans fully enjoy the possibility — the choice and responsibility—of redeploying this embodied reservoir into a broader and deeper sense of companionship. Interpreted through Pugno's lens, Vallorani's ambiguous title, Si muore bambini, might suggest a further interpretation: we all die children — we all die victimized perpetratorswhen we lose or deny biophilia. This is why, as Vallorani writes in "Cosa va e non va in TV," "[è] istruttivo questo guardare e riguardare la propria morte pubblica" (114), as it reveals the toxic socio-environmental impact of a barely perceivable "inner death." Recalling Elena Past's distinction of crime fiction as belonging either to the Lombrosian approach concerned with exploring criminal behaviour in detail, or to the Beccarian approach, which considers a single criminal action as illustrative of broader social issues, we can see how the fairy-tale noir repurposes this latter approach by fostering the idea that, in investigating crime, "the system, and not the criminal, is the primary object of the study" (15).

The systemic representation of violence as the aftermath of a collective loss of humanness, biophilia, and interspecies pietas emerges in the fairy-tale noir's idiosyncratic characterizations of victims as punishers. While, for instance, crime fiction novelist Massimo Carlotto distinguishes his noir writing - narratives that explore "il punto di vista del Male" (qtd. in Frezzato 112)—from his hard-boiled productions - which still convey an ethical stance though a leading detective figure-in the fairy-tale noir this separation becomes trickier. Is Cal a victim or a 
perpetrator? Are his murderous ethics even able to be categorized according to the good/evil moral framework, or are they utterly inhuman? The vicious circle of violence that makes abusers indistinguishable from their victims similarly appears in Si muore bambini, in which Vallorani narrates the story of Ariel, a girl featured in several snuff movies. Physically and emotionally abused, she is now a "wolf-punisher" with "una bella doppia fila di zanne azzurre, deliziose, efficienti" (85), who tries to protect younger girls from a similar destiny. And Selhoua, the protagonist of Vallorani's short story "L'ultimo scatto," is a peculiar vindicator. A journalist, Selhoua is covering the case of a serial killer of children. In the end, she is revealed to be the unaware abused abuser: guided by her own inner "Ogre," she has been acting as a "motherly" killer who reduces the pain of abused children by killing them in their houses.

Adopting a Beccarian view, women authors have developed a discourse about crime that more closely connects domestic abuse to the ecosystem at large. The fairy-tale noir, through its systemic mapping of shared areas of vulnerability and its redefinition of environmentalist family bonds, shows how the development of familiar attitudes towards the environment is strictly connected to a recasting of family as a positive space of encounter. Yet noir narratives, in their unresolved intricacy, emphasize that "learning through encounters with other [bodies and other] species is not always harmonious and pleasant, is not always equal, and does not offer us 'moral certitudes or simple escape routes'" (Haraway 115). To be communities that nourish kinship with zoe, families must reconsider the meaning of violence, respect, and humanness through a non-hierarchical animal perspective.

\section{Conclusion}

The fairy-tale noir is a subgenre that deserves further attention by the scholarship investigating the multifaceted developments of the Italian giallo. Through the re-contextualization of mermaids, ghosts, speaking animals, hunters, and abused children into twenty-first-century dark fables, this cross-genre not only voices new social concerns but also offers a different lens to compare the Nuovo Giallo Italiano with other noir traditions. As for British and American works, besides the aforementioned feminist narratives of Sexton and Carter, more-recent examples of noir reuse and "remediation" of fairy tales include Bill Willingham's Fables, a comic published from 2002 to 2015, which also led to a gaming spin-off, The Wolf among Us, and TV shows such as Once Upon a Time and Grimm. Generally 
speaking, while these works have experimented with a "noirization" of the fairytale genre, the texts of Italian women authors, rather, have added fantasy nuances to the popular genre of the noir and repurposed its male-dominated tradition into a space that redeploys female vulnerability into a feminist-environmentalist discourse of exposure.

Drawing from both the inability of fairy tales to be fully appropriated-in part due to their orality - and their narratives of human-nonhuman co-agency, the fairy-tale noir shows the two-fold nature of vulnerability: while it opens up a path to a number of transformative social and environmentalist uses, it also leaves bodies more exposed to abuse. Vulnerability has become a key theme in interpreting the changes that Italian families have been facing in the last few decades. The fairy-tale noir suggests that families find their common destiny not so much in an idealized (and often strictly heteronormative) model, but more so in the delicate economy of affects that are shared by all, beyond the gender and sexual orientation of their members. At an environmental level, the family construct is broadened to embrace a non-speciesist kinship founded on the idea that "any adequate feminist $[\ldots]$ politics will be non-anthropocentric, rejecting value dualisms that are oppositional and hierarchical, such as the human/animal dualism" (Adam 79-80). From a feminist view, which posits zoe as an immanent force that is inclusive of humans, children's biophilia acquires a fundamental value. If in the fairy-tale noir children are allegorical figures of fragility, they also embody the starting point of a culture opened-yet inevitably more exposed—to (bio-)diversity in domestic, social, and natural environments.

\section{Colby College}

\section{Works Cited}

Adam, Carol. "Bringing Peace Home: A Feminist Philosophical Perspective on the Abuse of Women, Children, and Pet Animals." Hypatia 9.2 (1994): 63-84. Agamben, Giorgio. The Use of Bodies. Trans. Adam Kotsko. Stanford: Stanford UP, 2016.

Alaimo, Stacy. Exposed: Environmental Politics and Pleasures in Posthuman Times. Minneapolis: U of Minnesota P, 2016. 
Amici, Marco. "La narrativa a tema criminale: poliziesco e noir per una critica politica." In Scritture di resistenza: sguardi politici dalla narrativa italiana contemporanea. Ed. Claudia Boscolo and Stefano Jossa. Rome: Carocci, 2014. 129-197.

Bettelheim, Bruno. The Use of Enchantment. London: Peregrine Books, 1978.

Braidotti, Rosi. "Four Theses on Posthuman Feminism." In Anthropocene Feminism. Ed. Richard Grusin. Minneapolis: U of Minnesota P, 2017. 21-48.

Carter, Angela. The Bloody Chamber and Other Stories. New York: Penguin, 1981. Deleuze, Gilles. "The Philosophy of Crime Novels." In Desert Islands and Other Texts 1953-1974. Ed. David Lapoujade. Trans. Michael Taormina. Los Angeles: Semiotext(e), 2004. 81-85.

Di Ciolla, Nicoletta. Uncertain Justice: Crimes and Retribution in Contemporary Italian Crime Fiction. Newcastle upon Tyne: Cambridge Scholars Publishing, 2010.

Di Ciolla, Nicoletta, and Mirna Cicioni, eds. Differences, Deceits and Desires: Murder and Mayhem in Italian Crime Fiction. Newark: U of Delaware P, 2008.

Donnarumma, Raffaele. "Laura Pugno - 'Sirene.” Review of Sirene by Laura Pugno. Allegoriaonline.it 57 (2007). http://www.allegoriaonline.it/index. php/raccolte-tremila-battute/allegoria-57-25069/240-laura-pugno-qsireneq. Accessed 30 Aug. 2017.

Frezzato, Enrichetta Lucilla. "From a Local to a Global Perspective in Crime Writing: On Massimo Carlotto, Impegno, and Respiro corto." Quaderni d'italianistica 37.1 (2016): 107-124.

Gilebbi, Matteo. "Witnessing the Slaughter: Human and Nonhuman Animals in Ivano Ferrari's Poetry." In Landscapes, Natures, Ecologies: Italy and the Environmental Humanities. Ed. Enrico Cesaretti, Serenella Iovino, and Elena Past. Charlottesville: U of Virginia P, 2018. 47-56., f47-56.

Giovannini, Fabio. Storia del noir. Dai fantasmi di Edgar Allan Poe al grande cinema di oggi. Rome: Castelvecchi, 2000.

Haraway, Donna. When Species Meet. Minneapolis: U of Minnesota P, 2007.

Herman, David. "Introduction: Literature beyond the Human." In Creatural Fictions: Human-Animal Relationships in Twentieth-and Twenty-First-Century Literature. Ed. David Herman. New York: Palgrave Macmillan, 2016. 1-15. Jansen, Monica, Inge Lanslots, and Dieter Vermandere. "Introduzione." In Noir de Noir. Un'indagine pluridisciplinare. Ed. Monica Jansen, Inge Lanslots, and Dieter Vermandere. Brussels: Peter Lang, 2010. 9-19. 
Krečič, Jela and Slavoj Žižek. "Ugly, Creepy, Disgusting, and Other Modes of Abjection.” Critical Inquiry 43 (2016): 60-83.

La Porta, Filippo. "Contro il Nuovo Giallo Italiano (e se avessimo trovato il genere a noi congeniale?)." In Sul banco dei cattivi: a proposito di Baricco e di altri scrittori alla moda. Ed. Alfonso Berardinelli and Giulio Ferroni. Rome: Donzelli, 2006. 55-75.

Macchiavelli, Loriano. "L'Italia ha ucciso il romanzo noir." Il Fatto Quotidiano 2 July 2017: 1, 19.

. "Loriano Macchiavelli e il destino del giallo." Interview with Maria

Agostinelli. http://www.loriano-macchiavelli.it/interviste/destino-giallo/. Accessed 30 Aug. 2017.

Maher, Brigid, and Barbara Pezzotti. "Hybridity in Giallo: The Fruitful Marriage Between Italian Crime Fiction and Theatre, Literary Geographies, and Historical and Literary Fiction." Quaderni d'italianistica 37.1 (2016): 9-16.

Marchesini, Roberto. Posthuman. Verso nuovi modelli di esistenza. Turin: Bollati Boringhieri, 2001.

Mondello, Elisabetta, ed. Roma Noir 2005. Tendenze di un nuovo genere metropolitano. Rome: Robin, 2005.

Morton, Timothy. Dark Ecology: For a Logic of Future Coexistence. New York: Columbia UP, 2016.

Nancy, Jean-Luc. "Shattered Love." In The Inoperative Community. Ed. Peter Connor. Trans. Lisa Garbus and Simona Sawhey. Minneapolis: U of Minnesota P, 1991. 82-109.

Past, Elena. Methods of Murder: Beccarian Introspection and Lombrosian Vivisection in Italian Crime Fiction. Toronto: U of Toronto P, 2012.

Pieri, Giuliana, and Francesca Rinaldi. "Italian Women Crime Writers." In Italian Crime Fiction. Ed. Giuliana Pieri. Cardiff: U of Wales P, 2011. 115-131.

Pugno, Laura. La caccia. Milan: Ponte alle Grazie, 2012. . La ragazza selvaggia. Venice: Marsilio, 2016.

. Personal interview. 19 Feb. 2017. . Sirene. Turin: Einaudi, 2007.

Ratelle, Amy. Animality and Children's Literature and Film. New York: Palgrave Macmillan, 2015.

Rushing, Robert. "Sirens without Us: The Future after Humanity." California Italian Studies 2.1 (2011). http://escholarship.org/uc/item/0cc3b56b. Accessed 12 Aug. 2017. 
Serpell, James. "Working Out the Beast: An Alternative History of Western Humaneness." In Child Abuse, Domestic Violence, and Animal Abuse: Linking the Circles of Compassion for Prevention and Intervention. Ed. Frank R. Ascione and Phil Arkow. West Lafayette: Purdue UP, 1999. 38-49.

Seven. Directed by David Fincher. New Line Cinema, 1995.

Sexton, Anne. Transformations. Boston: Houghton Mifflin, 1971.

Somigli, Luca. "Form and Ideology in Italian Detective Fiction." Symposium: A Quarterly Journal in Modern Literatures 59.2 (2005): 67-69.

Tabanelli, Roberta. "Al di là del corpo: La narrativa (postumana) di Laura Pugno." Italian Culture 28.1 (2010): 3-20.

Teodorani, Alda. Belve. Vampiri e Mostri nella Cinecittà del futuro. Final cut. Rome: Cut-Up Edizioni, 2011.

. Interview. Stradanove. http://www.stradanove.net/interviste/personaggi/alda-teodorani. Accessed 27 Mar. 2017.

. "Paint it black." In La collezionista di organi. Rome: Profondo Rosso, 2017. 31-32.

Teodorani, Alda, and Simonetta T. Hofelzer. Animali da macello: una storia bestiale. Pitigliano: Stampa Alternativa, 2016.

Tolstoy, Leo. Anna Karenina. NetLibrary. Web.

Vallorani, Nicoletta. Cordelia. Novate Milanese: Prospero editore, 2016. . Si muore bambini. Ozzano dell'Emilia: Perdisa editore, 2008. . Visto dal cielo. Turin: Einaudi, 2004.

Verbeek, Peter, and Frans de Waal. "The Primate Relationship with Nature: Biophilia as a General Pattern." In Children and Nature: Psychological, Sociocultural, and Evolutionary. Ed. Peter H. Kahn and Stephen R. Keller. Boston: MIT P, 2002. 1-27.

Vinci, Simona. Brother and Sister. Turin: Einaudi, 2003. "La gabbia." The Dark Side. Ed. Roberto Santachiara. Turin: Einaudi, 2006. 405-415.

Wu Ming I. "Premessa alla versione 2.0 di New Italian Epic." Wumingfoundation. https://www.wumingfoundation.com/italiano/WM1_saggio_sul_new_italian_epic.pdf. 1-33. Accessed 30 Aug. 2017.

Zapf, Hubert. Literature as Cultural Ecology: Sustainable Texts. London, New York: Bloomsbury, 2016.

Zipes, Jack. The Brothers Grimm: From Enchanted Forests to the Modern World. New York: Palgrave Macmillan, 2002. 